\title{
Evolution of body size, vision, and biodiversity of coral-associated organisms: evidence from fossil crustaceans in cold- water coral and tropical coral ecosystems
}

Adiël A. Klompmaker ${ }^{1,2,3^{*}}$, Sten L. Jakobsen ${ }^{4}$ and Bodil W. Lauridsen ${ }^{5}$

\begin{abstract}
Background: Modern cold-water coral and tropical coral environments harbor a highly diverse and ecologically important macrofauna of crustaceans that face elevated extinction risks due to reef decline. The effect of environmental conditions acting on decapod crustaceans comparing these two habitats is poorly understood today and in deep time. Here, we compare the biodiversity, eye socket height as a proxy for eye size, and body size of decapods in fossil cold-water and tropical reefs that formed prior to human disturbance.

Results: We show that decapod biodiversity is higher in fossil tropical reefs from The Netherlands, Italy, and Spain compared to that of the exceptionally well-preserved Paleocene (Danian) cold-water reef/mound ecosystem from Faxe (Denmark), where decapod diversity is highest in a more heterogeneous, mixed bryozoan-coral habitat instead of in coral and bryozoan-dominated facies. The relatively low diversity at Faxe was not influenced substantially by the preceding Cretaceous/Paleogene extinction event that is not apparent in the standing diversity of decapods in our analyses, or by sampling, preservation, and/or a latitudinal diversity gradient. Instead, the lower availability of food and fewer hiding places for decapods may explain this low diversity. Furthermore, decapods from Faxe are larger than those from tropical waters for half of the comparisons, which may be caused by a lower number of predators, the delayed maturity, and the increased life span of crustaceans in deeper, colder waters. Finally, deep-water specimens of the benthic crab Caloxanthus from Faxe exhibit a larger eye socket size compared to congeneric specimens from tropical reefs, suggesting that dim light conditions favored the evolution of relatively large eyes.
\end{abstract}

Conclusions: The results suggest a strong habitat control on the biodiversity of crustaceans in coral-associated environments and that the diversity difference between deep, cold-water reefs and tropical reefs evolved at least $\sim 63$ million years ago. Futhermore, body size and vision in crustaceans evolved in response to environmental conditions in the deep sea. We highlight the usefulness of ancient reefs to study organismal evolution and ecology.

Keywords: Carbonates, Conservation, Corals, Crustacea, Decapoda, Ecology, Ecosystem engineer, Environment, Evolution, Reef

\footnotetext{
* Correspondence: adielklompmaker@gmail.com

${ }^{1}$ Florida Museum of Natural History, University of Florida, 1659 Museum

Road, PO Box 117800, Gainesville, Florida 32611, USA

${ }^{2}$ Oertijdmuseum De Groene Poort, Bosscheweg 80, NL-5283 WB Boxtel, The

Netherlands

${ }^{3}$ Department of Integrative Biology and Museum of Paleontology, University

of California, Berkeley, 1005 Valley Life Sciences Building \#3140, Berkeley,

California 94720, USA

Full list of author information is available at the end of the article
} 


\section{Background}

Although modern cold-water coral ecosystems are much less studied than their warm, shallow-water reef counterparts, they have received considerable attention in the last decade [1-6]. This is in part because these ecosystems are under threat as are tropical reefs and their associated biodiversity [3, 7-11]. The number of reef-building coral species is relatively low for cold-water coral carbonate reefs/mounds sensu [4] in modern and fossil ecosystems $[12,13]$. The diversity of associated organisms in modern cold-water habitats might be comparable to the diversity found in tropical coral reefs [5], but the sparse data thus far suggests that diversity is lower in cold-water coral ecosystems $[4,14,15]$. Compared to their direct surroundings, cold-water reefs/mounds are regarded as biodiversity hotspots and the biodiversity of associated organisms is relatively high $[4,5,12,16-18]$, despite their limited areal extent compared to other deep-water habitats [18]. Cold-water coral ecosystems likely represent important speciation centers and glacial refugia in the deep sea [5], can alter hydrography [19], and provide a habitat, food source, and nurseries for various taxa [10, 17]. Thus, they can be considered ecosystem engineers [20,21].

One of the taxa associated with corals are the highly diverse decapods $[15,22-24]$, crustaceans that have an extensive fossil record and frequently inhabited tropical reefs in the Meso- and Cenozoic [25-31]. Decapods are usually abundant in and around modern cold-water reefs [15, 16, 24, 32-40], with carid and penaeoid shrimps often comprising the majority of the decapod specimens
$[33,36]$, but true crabs and squat lobsters are also found frequently. This pattern is also reflected in the species composition to some extent (Table 1). Although sampling may not have been exhaustive, species richness is typically $<30$ inside or very near to deep-water $(200+\mathrm{m})$ coral patches, whereas $>30$ species are usually found in modern tropical coral reefs (Table 1). The coral framework and the sediments surrounding deep-water corals serve for feeding purposes and as a shelter [17, 33, 34, 36, 39]. Some reports mention that the coral framework contains fewer specimens and species than nearby areas $[35,36]$. As is often the case for the number of specimens per taxon, decapod size is rarely recorded with one exception where carid and penaeid shrimp and lobster carapace lengths were compared in- and outside the coral framework [36].

These crustaceans have rarely been studied from fossil cold-water coral ecosystems, in part because such deposits appear less abundant than their warm, shallow-water reef counterparts [41-43]. Usually, decapods from fossil coldwater coral deposits are mentioned only briefly [44-47], except from the Paleocene (middle Danian) of Faxe in Denmark, where they are well-preserved and welldocumented taxonomically [48-56].

The mounds at Faxe (or Fakse) are formed predominantly by the frame-building coral Dendrophyllia candelabrum [57], with minor occurrences of Oculina becki [58] and Faksephyllia faxoensis [59]. This ancient ecosystem consisted of numerous individual mounds of 50-100 $\mathrm{m}$ in diameter, resulting from complex interactions between

Table 1 The number of decapod species found in or around modern coral habitats. The cold, deep-water coral environments overlap in terms of depth with the inferred depth of the Paleocene (Danian) Faxe coral-bearing deposits in Denmark (200-400 m, [13]). For comparison, species richness is also shown for some shallow-water, tropical coral reefs

\begin{tabular}{|c|c|c|c|c|c|c|c|c|c|c|}
\hline $\begin{array}{l}\text { Closest country/ } \\
\text { region }\end{array}$ & $\begin{array}{l}\text { Water depth } \\
(\mathrm{m})\end{array}$ & $\begin{array}{l}\text { Number } \\
\text { of species }\end{array}$ & $\begin{array}{l}\text { True crabs } \\
\text { (Brachyura) }\end{array}$ & $\begin{array}{l}\text { Squat lobsters } \\
\text { (Galatheoidea) }\end{array}$ & $\begin{array}{l}\text { Other } \\
\text { lobsters }\end{array}$ & $\begin{array}{l}\text { Shrimps } \\
\text { (Penaeoidea) }\end{array}$ & $\begin{array}{l}\text { Shrimps } \\
\text { (Caridea) }\end{array}$ & $\begin{array}{l}\text { Hermit crabs } \\
\text { (Paguroidea) }\end{array}$ & $\begin{array}{l}\text { Other } \\
\text { Anomura }\end{array}$ & Reference \\
\hline Norway & $240-290$ & 3 & 1 & 1 & & & & & 1 & {$[32]$} \\
\hline Norway (Sula) & $275-295$ & 5 & & 1 & & & 4 & & & [128] \\
\hline Italy & $350-1100$ & 7 & 1 & & 2 & 2 & 2 & & & [36] \\
\hline Italy (Sardinia) & $380-460$ & 7 & 4 & 1 & & & 2 & & & {$[40]$} \\
\hline Italy ${ }^{a}$ & $280-1121$ & 20 & 7 & 2 & 2 & 3 & 6 & & & [35] \\
\hline USA (Alaska) & $161-365$ & $2+$ & & & & & & & & [33] \\
\hline $\begin{array}{l}\text { Colombia } \\
\text { (Caribbean) }\end{array}$ & $200-220$ & 27 & 14 & 1 & & & 5 & 6 & 1 & [129] \\
\hline Canada & $246-630$ & 2 & & & & & & & & [15] \\
\hline $\begin{array}{l}\text { Panama (Pacific, } \\
3 \text { localities) }\end{array}$ & $\begin{array}{l}\text { 2, shallow } \\
\text { subtidal }\end{array}$ & $37-55$ & & & & & & & & $\begin{array}{l}{[69,130,} \\
131]\end{array}$ \\
\hline $\begin{array}{l}\text { Cuba (reef flat, } \\
3 \text { localities) }\end{array}$ & $\leq 5$ & $36-40$ & & & & & & & & [132] \\
\hline $\begin{array}{l}\text { W Australia } \\
\text { (3 localities) }^{b}\end{array}$ & $\leq 2$ & $26-32$ & & & & & & & & [133] \\
\hline $\begin{array}{l}\text { Central Pacific } \\
(5 \text { localities })^{b}\end{array}$ & 10 & 68-191 & & & & & & & & [134] \\
\hline
\end{tabular}

alarge area and depth range, ${ }^{\mathrm{b}}$ collecting from corals only 
biological and geological processes [13]. Smaller bryozoan mounds and intervals with an octocoral-rich facies are interfingering with the larger coral mounds [60]. The corals grew in relatively deep water below the photic zone, between 200-400 m [13] in the mesopelagic zone. At such depths, only some light penetrates so that animals may still be able to detect objects against downwelling light [61]. A variety of associated organisms is found at Faxe including annelids, arthropods, brachiopods, bryozoans, echinoderms, and mollusks [51, 60, 62-64].

Faxe yields the best known fossil decapod fauna from a cold-water coral ecosystem by far [51], but decapod diversity differences within this varied environment have not been investigated. Furthermore, this unique cold-water fauna has not been compared to tropical counterparts in terms of biodiversity, body size, and eye size. Consequently, the effect of environmental conditions on decapod faunas in these two environments is not well-known. The biodiversity, body size, and eye size of these crustaceans is not compared extensively for today's cold-water coral and tropical coral environments, at least in part due to the cryptic nature of crustaceans in modern coral ecosystems, hampering unbiased collecting and comparisons. Such studies on extant coral habitats will get increasingly difficult due to coral decline worldwide [3, 7-11]. Here we use fossil decapods from coral-associated habitats that formed and ultimately vanished prior to human disturbance to test the following hypotheses:

1. Decapod diversity is higher in the coral facies compared to that from the intercalated bryozoan facies at Faxe.

2. Decapod biodiversity is higher in warm, shallowwater reefs compared to that from the cold-water mounds at Faxe.

3. Decapods from cold-water coral reefs/mounds are larger than those from shallow-water reefs, probably due to the lower number of predators in deeper waters and/or because of the physiology of crustaceans in deeper, relatively cold waters resulting in a delayed maturity and an increased life span.

4. Deeper water specimens from Faxe exhibit a relatively large eye socket size as an adaptation to increase light capture of downwelling and bioluminescent sources.

We show differences in decapod biodiversity within the Faxe mound ecosystem and among the cold-water reef/mounds at Faxe versus those from other European reefs. Carapace size differs significantly in part of the analyses comparing Faxe decapods to other assemblages. Finally, we report on significant differences in eye socket size of the benthic crab Caloxanthus from a deep-water setting compared to a shallower environment.

\section{Methods}

\section{Sampling}

Sampling took place at four sites in the Faxe Formation in the Faxe Quarry, Denmark [13, 60], on the southwestern wall directly below and slightly north of the Geomuseum Faxe $\left(55^{\circ} 15^{\prime} 20^{\prime \prime} \mathrm{N} / 12^{\circ} 07^{\prime} 26^{\prime \prime} \mathrm{E}-55^{\circ} 15^{\prime} 29^{\prime \prime} \mathrm{N} / 12^{\circ} 07^{\prime} 21^{\prime \prime} \mathrm{E}\right)$ (Fig. 1). Four in situ samples per site were extracted from a few square meters by filling a bucket of $22,850 \mathrm{~cm}^{3}$ for each sample. Volume instead of collecting time [29] was chosen here because of marked differences in hardness of the rock among the sites (more volume would be quarried for softer rocks in an equal amount of time). The

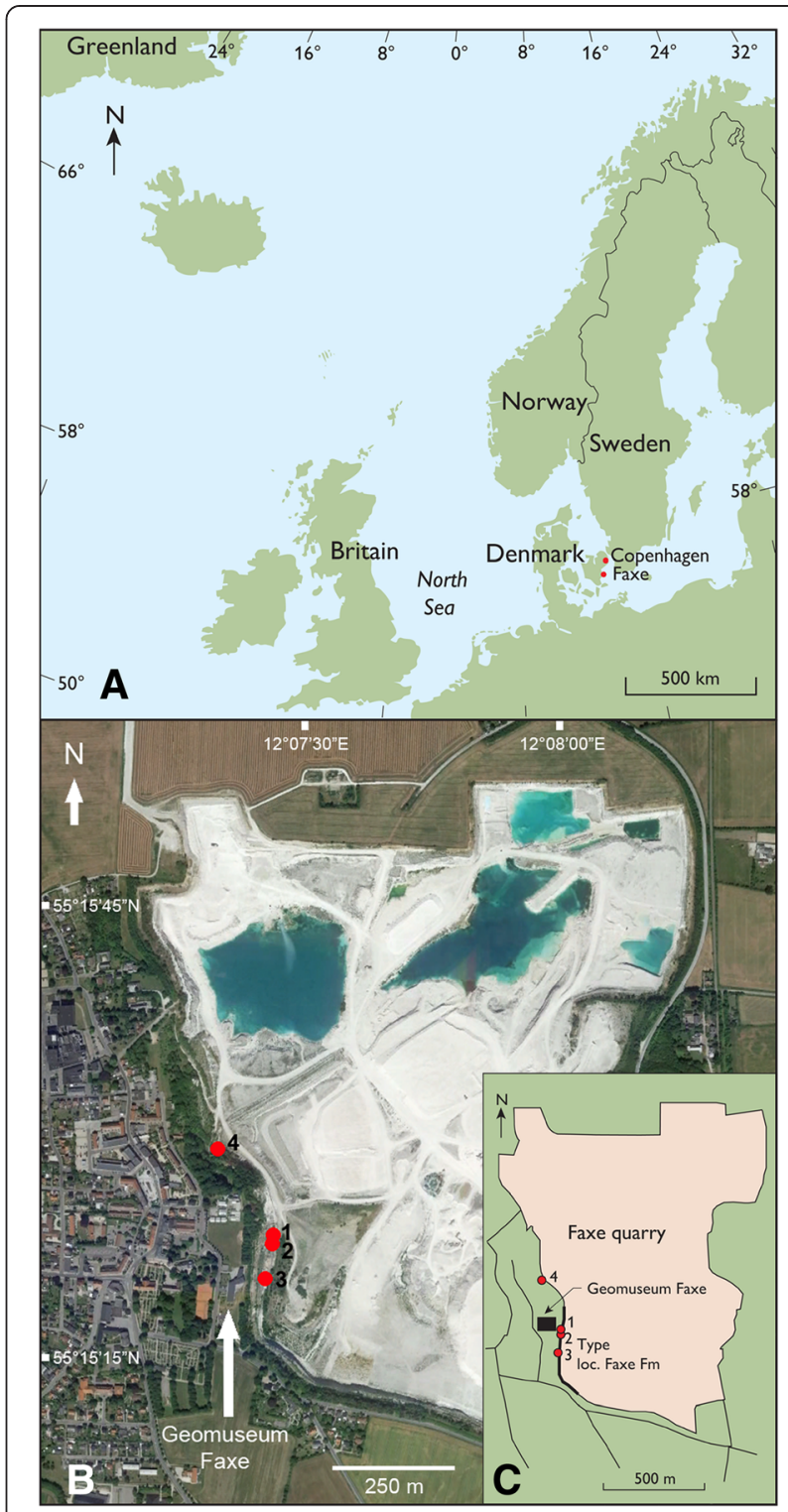

Fig. 1 The location of Faxe in Denmark in Europe and an overview of the Faxe Quarry. a Faxe in Europe. b, c The location of the four sample sites. Google Earth image (20 July 2013) of the Faxe Quarry, Sjæelland, Denmark 
rocks were broken into subequal pieces of a few $\mathrm{cm}^{3}$ subsequently and all decapods were collected. An approximately equal amount of time per site was spent in the sunshine because decapods may be observed more readily in the sun [29]. For all statistical analysis PAST 3.06 [65] and a significance level of $5 \%$ was used.

The four sample sites expose different facies. The samples collected directly west of (below) the Geomuseum Faxe consist of dense bryozoan-dominated rudstone with rare remains of corals, brachiopods, decapods, and bivalves (site 3). Over $80 \%$ of the limestone consists of bryozoa. The scleractinian coral dominated site (site 2), slightly to the north of site 3 and adjacent to the 'octocoral' site, consists of a dense network of branching coral bafflestone (Fig. 2). It consists predominantly of branches and colony fragments of the mound-forming coral Dendrophyllia candelabrum, often only some centimeters apart, in between which some brachiopods, gastropods, bivalves, and decapods are found. The octocoral packstone site (site 1), containing octocorals, scleractinians, and bryozoans primarily, is part of a domeshaped structure surrounded by coral bafflestones. Other associated fossils are brachiopods, gastropods, bivalves, and decapods. These three sites are part of the type locality of the Faxe Formation [60]. The northernmost bafflestone site (site 4) is composed of intermixed bryozoans and scleractinian corals, not as densely packed as the second site, but with many pockets filled with carbonate mud and abundant decapods as well as brachiopods, gastropods, and bivalves.

\section{Diversity}

For counting the number of specimens per species, a number of standardizations were carried out to minimize biases (see [29], for further discussion): (1) only internal molds (with or without cuticle) of carapaces with the axial part of the cervical groove preserved (a unique landmark) were counted; (2) specimens were collected by AAK only to minimize the possible effect of different sample strategies.

To investigate diversity differences among sites within the quarry, multiple measures of diversity were employed and all samples per site were merged for an adequate sample size for comparisons among sites. All specimens determined to the species-level were included in the analyses. However, $13-22 \%$ of the specimens per site could not be determined to the species-level due to their inadequate preservation, but only to the genus to superfamily-level. These specimens were assigned to species based on the relative proportion of species of the respective taxon at each site to increase sample size (Additional file 1: Table S1). Diversity per site was computed using: (1) species and genus richness, (2) individual rarefaction per site, and (3) the Shannon Index.

Decapod diversity of fossil cold, deep and warm, shallow-water coral-associated reefs sensu [66] was compared using the number of species and genera per locality for various localities in Europe (Faxe Quarry, Paleocene, Danian, Denmark; ENCI Quarry/St. Pietersberg, Upper Cretaceous, Maastrichtian, The Netherlands; Koskobilo Quarry, mid-Cretaceous, Albian, Spain; Contrada Gecchelina di Monte di Malo, lower Eocene, Ypresian, Italy; Braggi Quarry at Vestenanova, lower Eocene, Ypresian, Italy). All localities have been adequately sampled so that most species have been collected, they are found on the same continent, and they are exposing sediments with a minimum possible age range for suitable localities ( 50 Myr). Abundance data per species is unavailable for part of the localities, but they are for the Koskobilo and Faxe quarries so that diversity analyses (2) and (3) as above could be performed. All available specimens used here were systematically collected by AAK at both localities and samples were merged to increase sample size for all sites per locality.

\section{Body size}

The maximum carapace width of decapods was measured for each possible specimen collected in Faxe (measurements as in [29]). Width was chosen over length because width could be measured more easily for partial specimens due to the bilateral symmetry of decapods. The non-parametric Kruskal-Wallis test was used to compare widths among sites from the Faxe Quarry. The Mann-Whitney pairwise comparisons test (with and without a Bonferroni correction) was used to assess whether pairs differed significantly. The same was done for the two most abundant species: Dromiopsis elegans [67] and D. rugosus [68]. Carapace

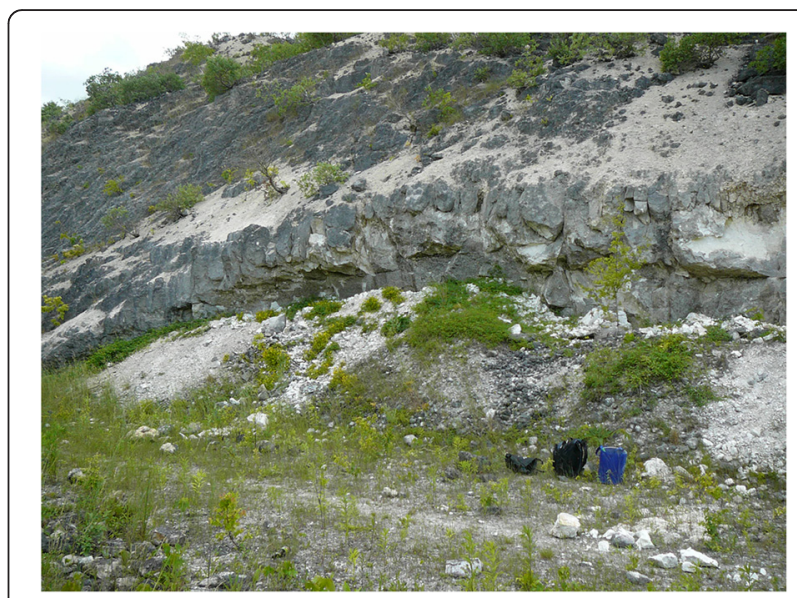

Fig. 2 Dome-shaped octocoral site (site 1) surrounded by scleractinian coral bafflestones. Sampling took place to the right of the small tree above the bucket (blue) at the level of the tree (see also Additional file 1: Figure S1). The site with the coral bafflestones (site 2) is located towards the left of the dome (not visible here). The bucket is $34 \mathrm{~cm}$ tall 
widths were also compared between Koskobilo (data from [29]) and Faxe using the Mann-Whitney test for all available data and for similar coral facies only (site 17 at Koskobilo and sites $2+4$ at Faxe) because decapod size may change per habitat [69], even within reefs [29].

Carapace widths (and geometric means where possible) of decapods and a subset (true crabs or Brachyura, the most speciose decapod clade) from Faxe were also compared, using the Mann-Whitney test, to those from the other localities with coral limestones as mentioned above. For this purpose, the maximum carapace width and length were recorded as derived from the literature or as measured herein. Furthermore, the maximum widths of crab genera abundantly present in both Faxe and Koskobilo (Caloxanthus and Faksecarcinus) were also compared. Also, the maximum widths of Dromiopsis praelaevior [70] from the ENCI Quarry and D. paucigranosa [27] from Contrada Gecchelina di Monte di Malo and the Braggi Quarry were compared to those of congenerics from Faxe. Dromiopsis mosae [70] was recently suggested not to originate from the ENCI Quarry [71] and was not used. As Brachyura are the most speciose decapod clade known from the Paleocene, the maximum widths and geometric means of reef-associated crabs from Faxe were compared to those of all other Paleocene crabs.

\section{Eye socket size}

Eye sockets (or orbits) are preserved for some decapod taxa and serve as a proxy for eye size. Eye socket height is measured here because socket width is frequently influenced by the eye stalks as well. As eye size is correlated with specimen size, carapace widths and lengths were also measured to obtain the geometric mean of the carapace. Differences in eye size between deep and shallow-water decapods are best expressed by comparing taxa within the same genus [72]. For that reason, eye socket heights of congeners from different inferred paleodepths are compared. The epifaunal crabs of Caloxanthus were used for this purpose because they are abundant in Faxe (Caloxanthus ornatus [48]) and are also commonly found in shallow-water coral-associated rocks from the Albian of Koskobilo (C. paraornatus [73]); a single specimen is reported from the Danian of Vigny ( $C$. vignyensis [74]). No other genera were suitable for this purpose.

Specimens of museum collections were studied to obtain eye socket height and carapace size of Caloxanthus. Specimens of comparable width $(\leq 6.5 \mathrm{~mm})$ and geometric size ( $\leq 5.6)$ of Caloxanthus from Faxe and Koskobilo with a comparable sample size were used for a one-way ANCOVA analysis to compare the adjusted means and slopes. Using specimens of similar carapace size is important because eye size tends to scale with body size, but the performance of eyes (e.g., spatial resolution and sensitivity) improves as absolute size increases [61].

\section{Results}

Diversity and taphonomy sample sites at Faxe

Species that are almost always found at each site are Dromiopsis rugosus, D. elegans, Protomunida munidoides [49], Galathea strigifera [48], and Caloxanthus ornatus (Fig. 3; Additional file 1: Table S1). Dromiopsis elegans is the most common species at each site, except for site 2 where $D$. rugosus is represented by one more specimen. Species and genus richness (Table 2), rarefaction analyses (Fig. 4), and the Shannon Index (Fig. 5) all suggest that site 4 is most diverse. These results were replicated when specimens not determined to the species-level were excluded.

Rocks at all sites were lithified, but the carbonates at sites 1 and 3 were softer and more friable than other sites. This did not affect the recognition of decapods substantially, with the possible exception of site 1 where decapods were less well-preserved. All specimens used consist of complete or partial dorsal carapaces without venters and appendages attached. Cuticle is preserved occasionally, but this did not influence the identification of specimens to the species-level here [74] because the taxonomy of decapods from Faxe is well-known $[51,55]$. Shrimps, abundant in modern cold-water corals habitats (Table 1), were absent.

\section{Diversity Faxe vs other European coral-associated localities}

Species richness comparisons indicate that both the number of decapod genera and species is lowest at Faxe (Table 3), and rarefaction analyses show a lower diversity at Faxe compared to Koskobilo (Fig. 6). The Shannon Index of Faxe (1.71; $95 \%$ confidence interval: 1.60-1.82) is also lower than that of Koskobilo (2.42; 2.30-2.56).

\section{Body size}

Decapod widths per site at Faxe differ significantly (Kruskal-Wallis $H=15.2, p=0.002$ ) (data: Additional file 1: Table S2). After a Bonferroni correction, only the median sizes of sites 2 and 4 differ significantly using the MannWhitney test (medians 7.56 and $4.46 \mathrm{~mm}$, resp.) (Table 4). Using only the two most abundant species yielded no significant differences (Dromiopsis elegans: Kruskal-Wallis $H$ $=7.5, p=0.06 ;$ D. rugosus: Kruskal-Wallis $H=4.7, p=0.10$ ).

Comparing all decapod size data based on collected specimens from all sites at Faxe and Koskobilo yielded no significant difference (Mann-Whitney $U=0.0002$, $p=0.89$ ). However, when decapods from comparable facies (coral boundstones) were analyzed, decapods from Faxe were larger than those of Koskobilo (Mann-Whitney $U=5322, p=0.006$; medians 4.8 vs $4.1 \mathrm{~mm}$, resp.). 
Comparing the maximum sizes of decapod species from Faxe to those from other coral-associated localities (Additional file 1: Tables S3-7) showed that part of the assemblages were statistically indistinguishable, whereas Faxe decapods were larger in half of the tests (Table 5). A larger size is also observed for the benthic crab Caloxanthus: maximum width for the species from Faxe is $13.8 \mathrm{~mm}(n=85)$, whereas the maximum width is $6.6 \mathrm{~mm}$ $(n=27)$ for Koskobilo (Additional file 1: Table S8). A Mann-Whitney test on Caloxanthus specimens of both samples shows statistical difference between the medians $(U=221.5, p<0.00001)$. The single specimen of Caloxanthus known from the shallow-water, coral-associated Danian of Vigny [74] is also smaller $(6.5 \mathrm{~mm})$ than the maximum size of Caloxanthus from Faxe. Conversely, the maximum width of the swimming crab Faksecarcinus appears larger in Koskobilo $(17.5 \mathrm{~mm}, n=9)$ compared to Faxe (13.6 $\mathrm{mm}, n=16)$ (Additional file 1: Table S8), but the medians are not statistically significant (Mann-Whitney $U=44, p=0.12$ ). Although Dromiopsis praelaevior from the ENCI Quarry is only known from a single specimen [70], it exhibits a smaller maximum width compared to all four congenerics from Faxe (Additional file 1: Tables S3-7). Likewise, specimens of Dromiopsis paucigranosa from Contrada Gecchelina di Monte di Malo and the Braggi Quarry [27, 31] are smaller than Dromiopsis spp. from Faxe (Additional file 1: Tables S3-7).
Finally, the width and geometric means of Faxe crabs and all other Paleocene crabs (Additional file 1: Table S9) do not differ significantly (Mann-Whitney $U$-values: 453, 432; $p$-values: $0.62,0.72$, resp.).

\section{Eye socket size}

The trend line of eye socket height versus maximum carapace width of $C$. paraornatus plots below that of $C$. ornatus (Fig. 7; Additional file 1: Table S8). A one-way ANCOVA test suggests that the slopes do not differ ( $F=1.46, p=0.23)$, but the adjusted means do $(F=17.34$, $p=0.0002)$, indicating that eye socket height is significantly greater for similar-sized specimens from Faxe. Similar results are obtained when using the geometric mean $(F=2.10, p=0.16 ; F=8.77, p=0.006$, resp. $)$. The eye socket height of the single specimen of $C$. vignyensis is smaller relative to the other species for the same carapace width.

\section{Discussion}

\section{Diversity and taphonomy sample sites at Faxe}

The hypothesis that decapod diversity is higher in coral facies compared to that of the intercalated bryozoan facies is partially supported. The coral-dominated facies (site 2) harbors a higher diversity compared to the bryozoan-dominated facies (site 3) (Figs. 4 and 5; Table 2). This is consistent with the suggestion that decapod

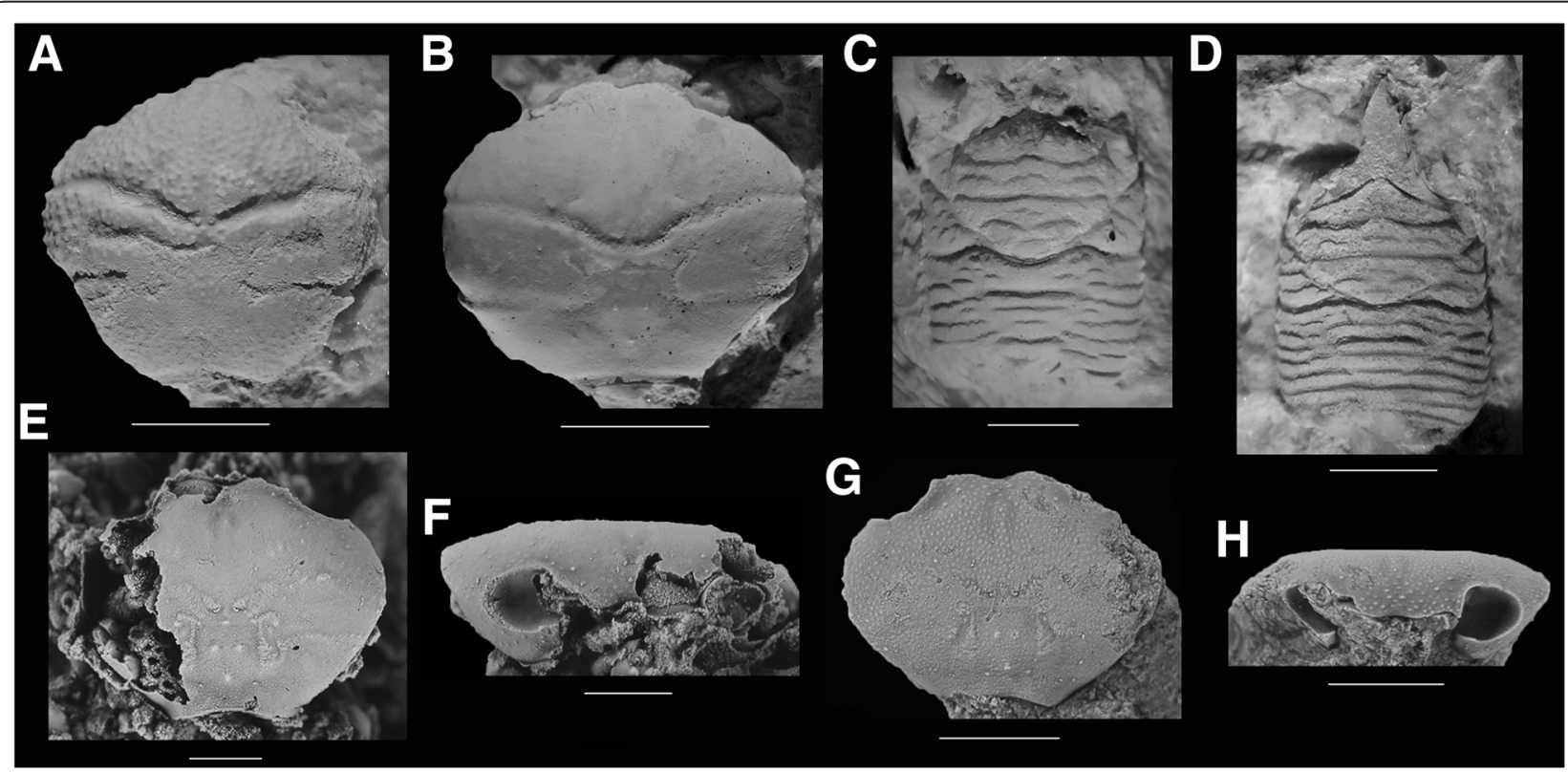

Fig. 3 Carapaces of common decapod species from Faxe and one from Koskobilo. Carapaces from the Paleocene (middle Danian) of Faxe, Denmark (a-f), and a carapace from the Albian of Koskobilo, Spain ( $\mathbf{g}-\mathbf{h})$, for comparison. a Dromiopsis rugosus (UF 256316). b Dromiopsis elegans (UF 256314). c Protomunida munidoides (UF 256317). d Galathea strigifera (UF 256315). e, f Caloxanthus ornatus (dorsal and frontal view showing right orbit, MAB k3153). $\mathbf{g}, \mathbf{h}$ Caloxanthus paraornatus (dorsal and frontal view showing left orbit, MGSB 77703, holotype). Permission to use $\mathbf{e}-\mathbf{h}$ [73] by The Palaeontological Association. Scale bar width: $5.0 \mathrm{~mm}$ for A-B; $2.0 \mathrm{~mm}$ for rest. 
Table 2 Decapod abundance and taxon richness per site

\begin{tabular}{lllll}
\hline & site 1 (octocoral packstone) & site 2 (bryozoan rudstone) & site 3 (scleractinian coral bafflestone) & $\begin{array}{l}\text { site } 4 \text { (scleractinian } \\
\text { coral-bryozoan bafflestone) }\end{array}$ \\
\hline \# specimens & 27 & 32 & 9 & 141 \\
\# species & 5 & 5 & 3 & 11 \\
\# genera & 4 & 4 & 3 & 9 \\
\hline
\end{tabular}

diversity in Eocene bryozoan-associated limestones from the USA (South Carolina) was lower than in coralassociated limestones in Europe, primarily due to ecological differences [75]. Although modern bryozoan habitats also contain a diverse, mostly facultative associated fauna including decapods [76-79], the relative diversity of this fauna compared that of coral reefs is unknown. At Faxe, decapod diversity and abundance is highest in the facies dominated by a mixture of bryozoans and scleractinian corals. This result cannot be explained by preservational differences because the coral-dominated site is composed of bafflestones of about equal hardness, whereas the bryozoan-dominated site is slightly softer, but decapod preservation is largely similar. The extensive, dense network of monotonous branching corals of primarily Dendrophyllia candelabrum at site 2 (only some centimeters between each branch) probably precluded inhabitation of an abundant, diverse decapod fauna, whereas a more varied, open framework with a higher number of microhabitats at site 4 attracted more decapods. This result may be consistent with data from modern cold-water coral habitats because: (1) the coral framework itself seems to harbor a relatively low diversity $[7,35,36]$ and (2) habitat heterogeneity appears to promote diversity $[34,69,80]$. The difference in abundance between sites 2 and 4 is partly caused by

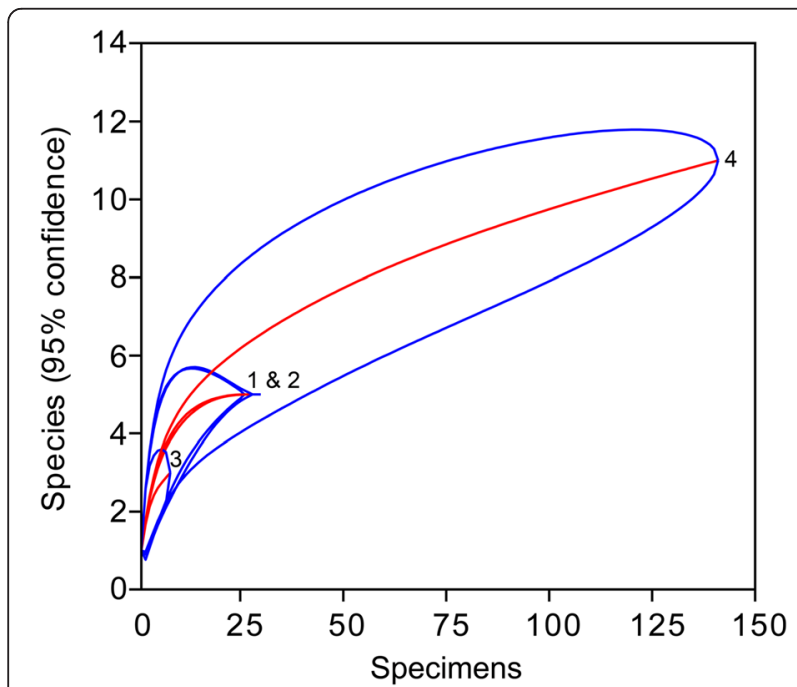

Fig. 4 Rarefaction curves for decapods of the four sites with $95 \%$ confidence intervals. The slopes of the means (middle lines) suggest that site 4 exhibits the highest diversity galatheoids that make up $54 \%$ of the decapod fauna at site 4 , whereas squat lobsters are less abundant at other sites ( $\leq$ $33 \%)$. Preservation could have played a role for site 1 , where sediments are much softer and decapod preservation is less pristine regardless of carapace size compared to other sites. Previous work showed that decapod diversity and abundance was highest in a coral bafflestone from the mid-Cretaceous (Albian) of Spain [29] compared to more open habitats, also partially caused by abundant galatheoids (51\%) compared to two out of three other sites. As for many modern cold-water coral faunas (Table 1), true crabs and squat lobsters are common. Shrimps are most likely absent because they do not preserve well $[81,82]$.

\section{Diversity Faxe vs other European coral-associated localities}

The relatively low decapod diversity of Faxe compared to that of other European, Cretaceous-Paleogene localities associated with corals (Fig. 6; Table 3) can be explained by the environment in which these crustaceans lived. Whereas Faxe corals and the associated organisms inhabited in a deep, cold-water environment (200-400 m, [13]), other coral-associated limestones represent warm, shallow-water deposits as evidenced by the presence of, for example, algae $[27,29,31,83]$. This low diversity of decapods at Faxe is consistent with the relatively low number of reef-building

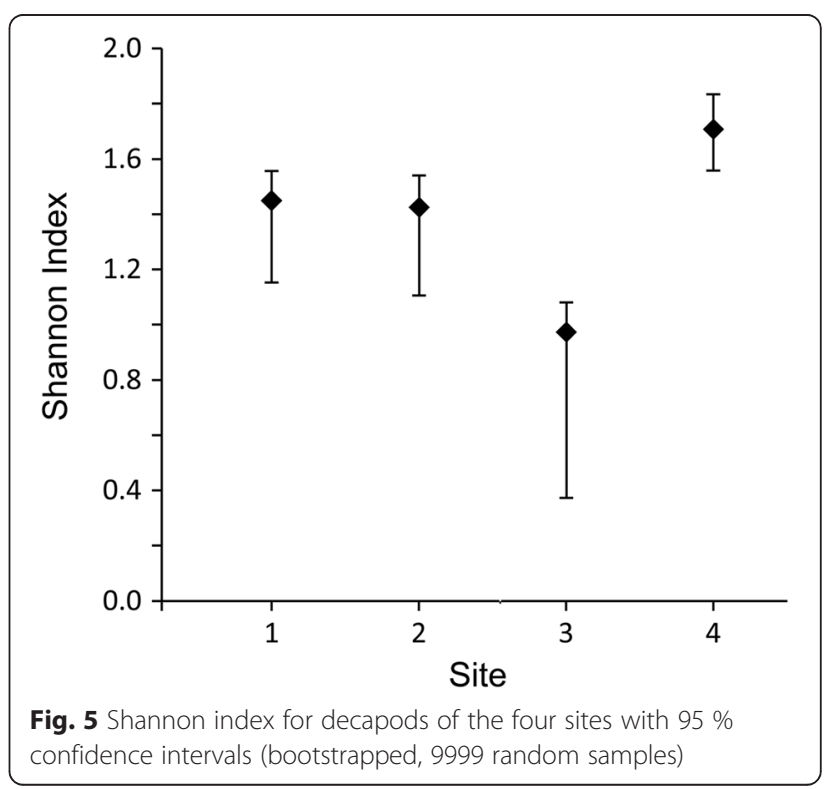


Table 3 Decapod species and genus richness per locality. Faxe is the only locality associated with cold-water corals; the rest is associated with warm, shallow-water associated corals

\begin{tabular}{llllll}
\hline & $\begin{array}{l}\text { Faxe, Denmark } \\
\text { (Paleocene, Danian) }\end{array}$ & $\begin{array}{l}\text { ENCI/St. Pietersberg, The Netherlands } \\
\text { (Upper Cretaceous, Maastrichtian) }\end{array}$ & $\begin{array}{l}\text { Koskobilo, Spain (mid- } \\
\text { Cretaceous, Albian) }\end{array}$ & $\begin{array}{l}\text { Contrada Gecchelina di Monte } \\
\text { di Malo, Italy (Eocene, Ypresian) }\end{array}$ & $\begin{array}{l}\text { Braggi Quarry at } \\
\text { Vestenanova, Italy } \\
\text { (Eocene, Ypresian) }\end{array}$ \\
\hline \# species & 25 & 29 & 38 & 48 & 46 \\
\# genera & 18 & 27 & 27 & 42 & 36 \\
\hline
\end{tabular}

Sources used: Faxe [51, 55, 135]; ENCI/St. Pietersberg ([70, 71, 136-142], RHB Fraaije and JWM Jagt, personal communication 2015); Koskobilo [73, 88, 143-149]; Contrada Gecchelina di Monte di Malo [27]; Braggi Quarry [31]

coral species in modern cold-water reefs [12] and the relatively low fish species richness [4] compared to tropical reefs. Although the data are limited thus far, corals of the deep also harbor a lower species diversity of gastropods, copepods, and decapods compared to their tropical counterparts (Table 1) [14, 15, 84].

Alternative explanations for this difference in biodiversity are (1) a lower sampling intensity for Faxe; (2) the fact that the Faxe fauna lived shortly after the Cretaceous/Paleogene extinction event [60, 85-87], which may have impacted decapod diversity as well; (3) a latitudinal signal; and (4) a lower preservation potential of decapods at Faxe. A lower sampling intensity is easily rejected because Faxe has been sampled extensively as > 5000 decapod specimens are known [51], which is more than, for example, Koskobilo [88]. Moreover, the rarefaction trajectories also suggest a lower diversity for Faxe compared to Koskobilo (Fig. 6). Previous work has suggested that the Cretaceous/Paleogene extinction event appears not to have severely impacted decapod diversity. Seventy-nine percent of decapod families survived into the Paleogene, and many genera were able to survive in the (sub)tropical Americas, relatively close to the

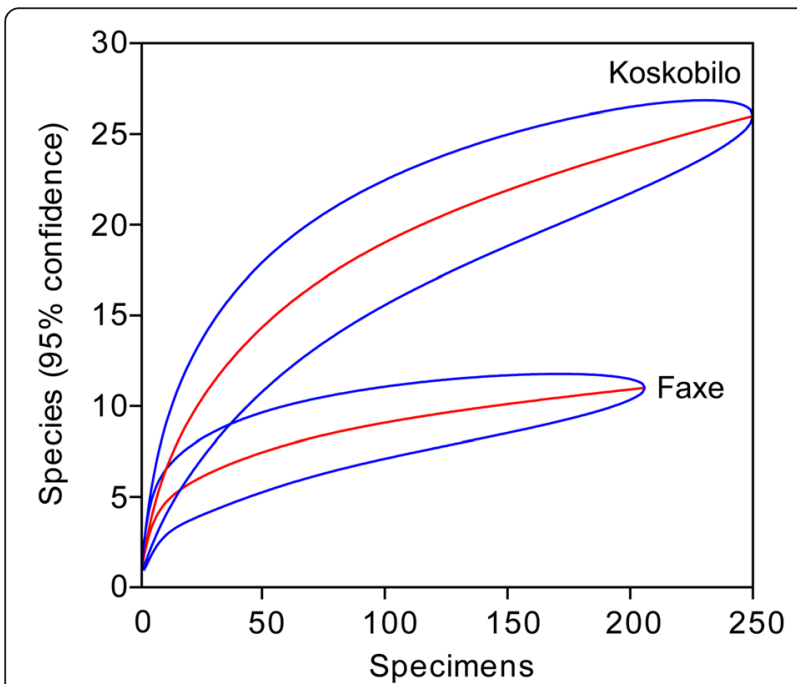

Fig. 6 Rarefaction curves for decapods of Faxe and Koskobilo with $95 \%$ confidence intervals. Both localities incorporate various microhabitats. Data for Koskobilo from [29]
Chicxulub impact site [89]. Brachyurans also appear hardly affected [90]. More regionally, $66 \%$ of the Danian crab genera in the Denmark - Sweden region were Cretaceous survivors [50]. Our new analyses of the uncorrected global standing decapod diversity show lower numbers of species and genera in the Danian than in the Maastrichtian. On the species-level, 120 decapod and 75 brachyuran species from the Maastrichtian are known [30], whereas 92 decapod and 55 brachyuran species have been reported from the subsequent Danian (e.g., [89, 91-95]) (Additional file 1: Tables S9-S10). Seventyfive decapod genera including 51 brachyurans are reported from the Maastrichtian, whereas 55 decapod genera including 36 crabs are known from the Danian. However, when adjusted for the unequal duration of both stages and the differences in rock outcrop area (Fig. 8; Additional file 1: Tables S10-11), the standing diversity does not drop for both taxonomic levels. Instead, Danian diversity is either approximately equal to that of the Maastrichtian or higher in the Danian. Unlike for many other organisms worldwide [86], these results suggest a limited signal of a mass extinction in decapods and true crabs across this interval. Another factor that may have influenced the patterns is latitude because modern decapod diversity increases towards the equator [96, 97]. However, all localities addressed herein are within a limited latitudinal range $\left(\sim 40-55^{\circ} \mathrm{N}\right)$ consistently throughout the Cretaceous-Paleogene, and the geographically (and temporally) closest locality to Faxe, the ENCI Quarry, is only $4.5^{\circ}$ south of Faxe. The decapod carapaces at Faxe are generally well-preserved, also in comparison to, for example, Koskobilo (pers. obs. AAK). In conclusion, the alternatives cannot fully explain to the relatively low decapod diversity in Faxe.

More likely, the pattern can be explained ecologically, consistent with observations from today's oceans that decapod diversity is lower in deep-water coral habitats (Table 1). Compared to warm, shallow-water reefs, corals at Faxe grew probably slower, likely yielding less food for mucus-feeding decapods and fewer places to hide. Additionally, less coral rubble is produced for these crustaceans to use as a habitat (decapods can also be common in this coral-derived habitat: [34, 36, 39, 69]). The results further imply that the decapod biodiversity 
Table 4 -values of the Mann-Whitney tests on decapod widths of the four sites at Faxe

\begin{tabular}{lllll}
\hline & site 1 (octocoral packstone) & site 2 (bryozoan rudstone) & site 3 (scleractinian coral bafflestone) & site 4 (scleractinian coral-bryozoan bafflestone) \\
\hline site $1-$ & 0.3362 & 0.3205 & $0.0301^{*}$ \\
site 2 & 1 & - & $0.0384^{*}$ & $0.0005^{*}$ \\
site 3 & 1 & 0.2301 & - & 0.9615 \\
site 4 & 0.1803 & $0.0031^{*}$ & 1 & - \\
\hline
\end{tabular}

Without (upper right) and with (lower left) Bonferroni correction applied; statistically significant results indicated by *

differences between deep, cold-water reefs and tropical reefs evolved at least $\sim 63$ million years ago, the age of the Faxe deposits [60].

\section{Body size}

The fact that little size variation of decapods exists at Faxe (Tables 4, Additional file 1: Table S2) suggests limited environmental control on body size for the four studied sites. Only sizes at site 4 are significantly smaller than those from site 2 . This difference is explained by the relatively high proportion of the small galatheoids at site 4 in combination with the relatively large specimens of $D$. rugosus at site 2 .

The hypothesis that decapods in cold waters are larger is mostly supported: decapods from deep, cold waters at Faxe are larger than those of Koskobilo when comparable facies are analyzed; half of the tests comparing decapod sizes of Faxe to the congeners of shallowerwater faunas return the same results, whereas the other tests showed no significant difference; sizes of Faksecarcinus are not statistically different for Faxe and Koskobilo; Caloxanthus from Faxe is larger than those from Koskobilo; and Dromiopsis spp. from Faxe is larger than Dromiopsis spp. from the ENCI Quarry and both Italian localities. The results are consistent with larger body sizes of various modern crustaceans including decapods at high latitudes and deeper, colder waters [96, 98-102]. An explanation for the evolution of large body size within genera and for assemblages may be related to crustacean physiology because crustaceans in deeper, colder waters experience delayed maturity, possess larger cells, and have an increased life span $[100,102,103]$. High latitudes also promote fewer and larger eggs for various crustaceans so as to increase fecundity, released during a period of optimum conditions [96, 104, 105]. Additionally, a lower impact of predators (e.g., fish) in cold-water reefs/ mounds may also have contributed to larger crustaceans $[106,107]$. A relatively low fish species richness is observed in modern cold-water reefs/mounds compared to tropical reefs [4], and fish species richness and abundance may be positively correlated [108, 109].

Interestingly, crab width from Faxe does not differ significantly from other Paleocene decapods (mostly from other habitats), but coral-associated decapods from the Cretaceous are smaller than those from other habitats [110]. These Cretaceous decapods are all associated with warm, shallow water coral habitats, in which a large size is not favored [110], whereas decapods from Faxe lived in colder, deeper waters. Hence, a larger size would be expected for these decapods.

\section{Eye socket size}

The hypothesis that deeper water specimens from Faxe exhibit a relatively larger eye socket size as an adaptation to increase light capture of downwelling and bioluminescent sources is supported. Eye socket heights of the benthic crab Caloxanthus from Faxe are significantly larger than those of Koskobilo. Moreover, a single specimen from the same geological stage as the Faxe deposits, from the shallow-water reef of Vigny [111, 112], exhibits a smaller eye socket compared to Caloxanthus from Faxe. These results are consistent with results from modern, congeneric benthic decapods: deep-water animals including decapods often have relatively large eyes to better detect objects in

Table 5 -values of Mann-Whitney tests comparing decapod sizes of Faxe to those of various other localities

\begin{tabular}{lcccc}
\hline & $\begin{array}{l}\text { ENCI/St. Pietersberg, The Netherlands } \\
\text { (Upper Cretaceous, Maastrichtian) }\end{array}$ & $\begin{array}{l}\text { Koskobilo, Spain } \\
\text { (mid-Cretaceous, Albian) }\end{array}$ & $\begin{array}{l}\text { Contrada Gecchelina di Monte } \\
\text { di Malo, Italy (Eocene, Ypresian) }\end{array}$ & $\begin{array}{l}\text { Braggi Quarry at Vestenanova, } \\
\text { Italy (Eocene, Ypresian) }\end{array}$ \\
\hline $\begin{array}{l}\text { Faxe (all decapods) - } \\
\text { width }\end{array}$ & 0.54 & $0.01^{*}$ & 0.70 & 0.13 \\
$\begin{array}{l}\text { Faxe (all crabs) - } \\
\text { width }\end{array}$ & 0.14 & $0.01^{*}$ & 0.69 & $0.01^{*}$ \\
$\begin{array}{l}\text { Faxe (all decapods) - } \\
\text { geometric mean }\end{array}$ & 0.32 & $0.05^{*}$ & - & - \\
$\begin{array}{l}\text { Faxe (all crabs) - } \\
\text { geometric mean }\end{array}$ & $0.05^{*}$ & $0.03^{*}$ & - & -
\end{tabular}

Statistically significant results indicated by *, all of which imply that Faxe decapods are larger. Length was infrequently available for taxa from the Italian localities; hence, no geometric means were used for comparisons 


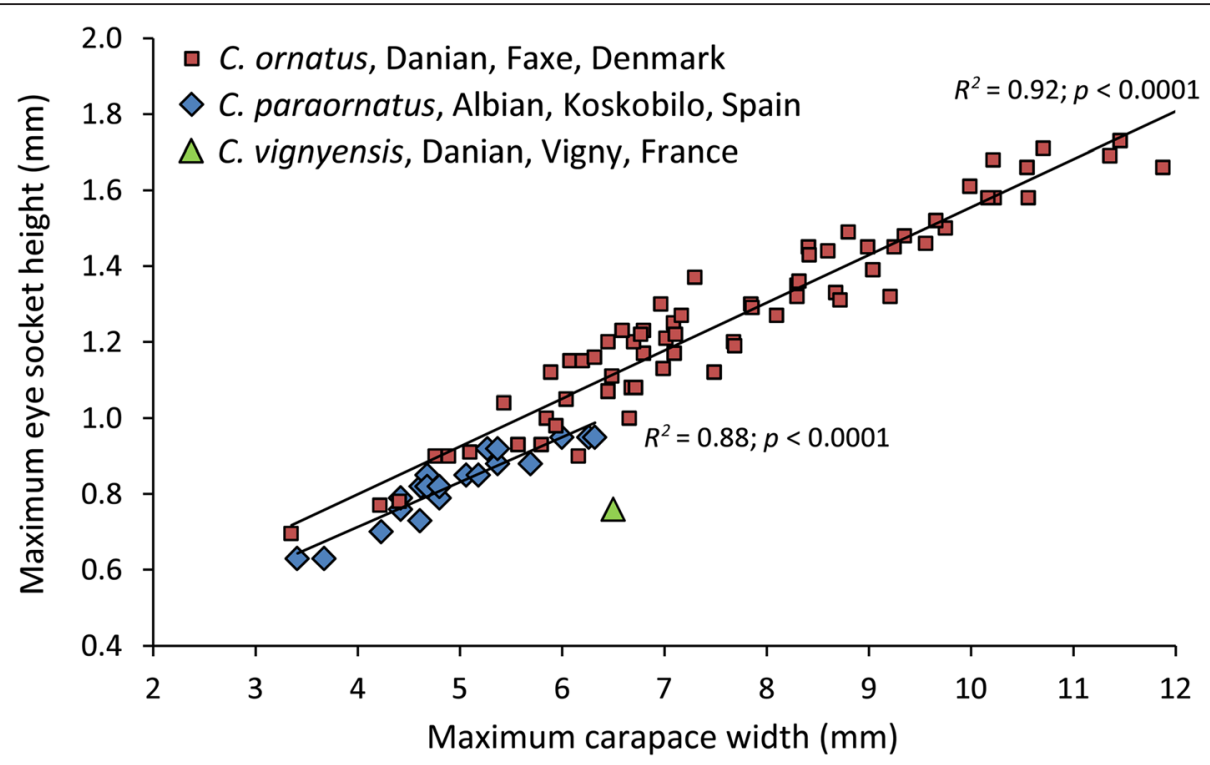

Fig. 7 Eye socket height of three species of the crab Caloxanthus vs the maximum carapace width

their dim environment [61, 72, 113]. Conversely, modern deeper water pelagic crustaceans appear to have smaller eyes resulting in a lower energetic burden, a lower weight, less drag, and eyes being less visible to predators [114, 115], a result not studied in fossil decapods thus far. This study shows that fossil decapod crustaceans can be used to study vision and ecology, which has rarely been documented thus far $[116,117]$ given the rare occurrence of fossil decapod eyes with the exception of specimens from KonservatLagerstätten [118-126].

\section{Conclusions}

1. A comparison of decapod crustaceans at different sites at the Paleocene cold-water reef/mound ecosystem from Faxe (Denmark) shows that diversity is highest at the coral-bryozoan dominated site, followed by the coral dominated site and the bryozoandominated site.

2. In agreement with the hypothesis, decapod biodiversity is higher in several fossil tropical reefs
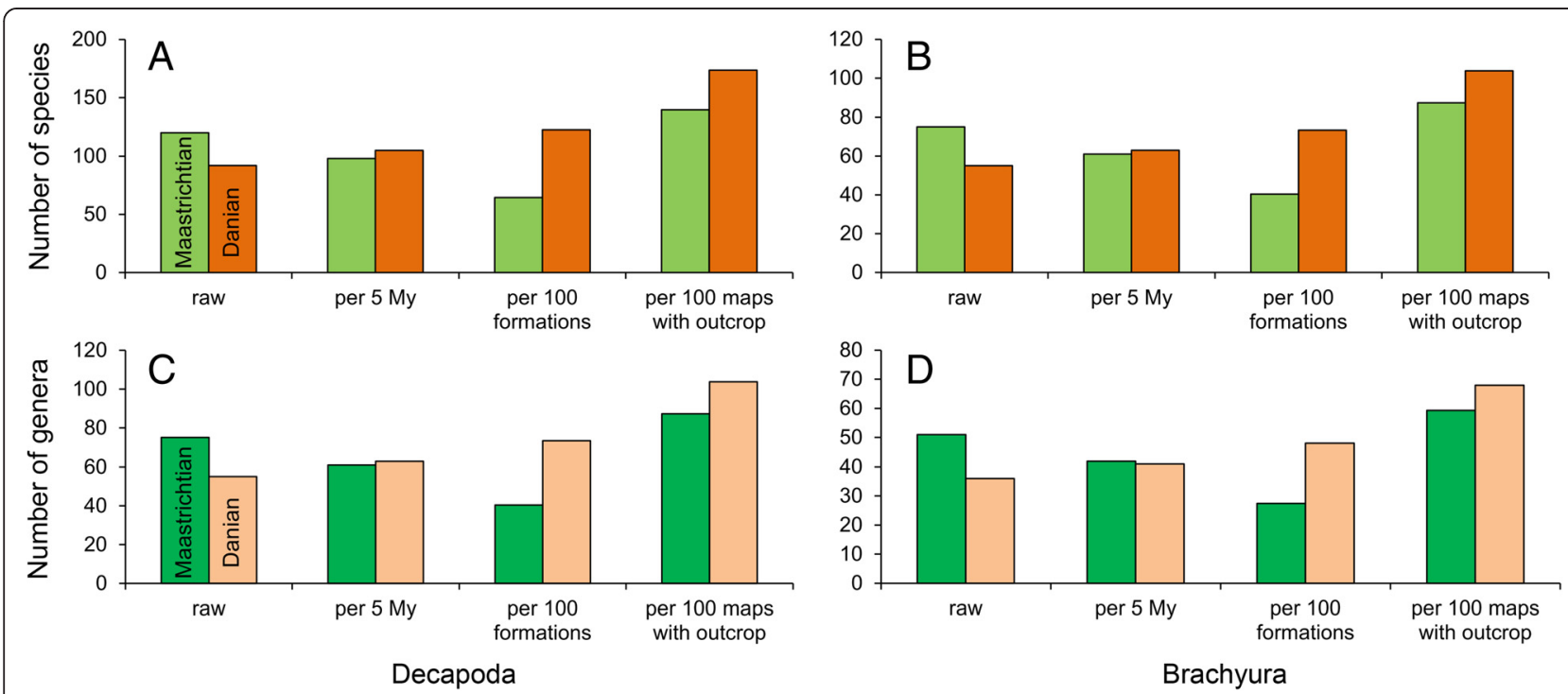

Fig. 8 Standing global diversity of decapods and Brachyura or true crabs across the Cretaceous/Paleogene boundary. Diversity is shown at the species- and genus-levels. Four sets of histograms are used to compare the number of taxa present in the Maastrichtian and the Danian: raw, standardized per 5 my, standardized per 100 marine formations globally as a proxy for outcrop area, and standardized per 100 maps with marine outcrops in Western Europe as a proxy for outcrop area [127]. a Decapod species. b Brachyuran species. c Decapod genera. d Brachyuran genera 
from Europe compared to that of Faxe using a variety of metrics. Thus, diversity differences between deep, cold-water reefs and tropical reefs evolved at least $\sim 63$ million years ago.

3. Decapods from Faxe are larger than those from warm, shallow waters from other localities for half of the analyses carried out, whereas the other half did not show significant differences. These results are in partial agreement with the hypothesis that decapods evolved larger sizes in cold-water coral reefs/mounds because of a lower number of predators, the delayed maturity, and the increased life span of crustaceans in deeper, colder waters.

4. In agreement with the hypothesis, deep-water specimens of the benthic crab Caloxanthus from Faxe exhibit a larger eye socket size compared to congeneric specimens from tropical reefs, suggesting that dim light conditions favored the evolution of relatively large eyes.

5. As shown by the body size and eye socket analyses, the effect of environmental conditions acting on the associated organisms of cold-water coral reefs/ mounds vs those in tropical reefs are clearly expressed in the morphology of decapod crustaceans.

\section{Additional file}

Additional file 1: Figure S1. Collecting sites Faxe. Table S1. Abundance data Faxe. Table S2. Size data Faxe. Table S3. Maximum size data Faxe. Table S4. Maximum size data ENCI/St. Pietersberg. Table S5. Maximum size data Koskobilo. Table S6. Maximum size data Contrada Gecchelina di Monte di Malo. Table S7. Maximum size data Braggi. Table S8. Carapace and eye socket size measurements. Table $\mathbf{S 9}$. Maximum size data of Paleocene crabs. Table S10. Maastrichtian and Danian decapod diversities. Table S11. Data used for Table S10. (DOCX 917 kb)

\section{Abbreviations \\ Specimens used in this study are housed in the Florida Museum of Natural History at the University of Florida (UF), Gainesville, Florida, USA; MAB k, Oertijdmuseum De Groene Poort, Boxtel, The Netherlands; MGSB, Museo Geológico del Seminario de Barcelona, Barcelona, Spain; MGUH, GM, Natural History Museum of Denmark, Geological Museum, University of Copenhagen, Denmark; OESM, Geomuseum Faxe, Faxe, Denmark; SNSB-BSPG, Bayerische Staatssammlung für Paläontologie und historische Geologie, München (Munich), Germany}

\section{Acknowledgements}

Emma Sheldon (The Geological Survey of Denmark and Greenland) is thanked for analyzing a sample with microfossils from Faxe (site 4); Morten Bjerager (The Geological Survey of Denmark and Greenland) for facilitating the latter; René Fraaije (Oertijdmuseum De Groene Poort) and John Jagt (Natuurhistorisch Museum Maastricht) for information on Dutch decapods from the ENCl Quarry; René Fraaije and Jesper Milàn for access to specimens from the Oertijdmuseum and the Geomuseum Faxe, respectively; Roger Portell (Florida Museum of Natural History) for collection assistance; Cristina Robins (FLMNH) for checking on non-decapod specimens in each sample; Lea-Anne Henry (Heriot-Watt University) for literature; Michal Kowalewski (FLMNH) and Rodney Feldmann (Kent State University) for letters of support; The Palaeontological Association for permission to use Fig. 3e-h; contributors to the Paleobiology Database (PBDB) are thanked for assembling
Maastrichtian and Danian formation names; and the organizers and participants of the COCARDE Workshop in Copenhagen, Denmark, June 2014, for their support. We are grateful for very useful comments by two anonymous reviewers. This is University of Florida Contribution to Paleobiology 692 and PBDB publication 264

\section{Funding}

This work was funded by an Arthur James Boucot Research Grant (Paleontological Society), the Jon L. and Beverly A. Thompson Endowment Fund, and a COCARDE Workshop Grant (ESF) to AAK. BWL was financed by grants from the Carlsbergfondet and the Geocenter Denmark. Funding sources had no role in the study design, data collection, analysis and interpretation of the data, and during the writing and submission process.

\section{Availability of data and materials}

The datasets supporting the conclusions of this article are included within the article and its additional file 1 .

\section{Authors' contributions}

AAK designed study; all authors decided upon collecting localities; AAK and SLJ prepared specimens; AAK did statistical analyses; AAK wrote paper and $S L J$ and BWL provided important input; AAK made photographs and figures; all authors read and approved the final manuscript.

\section{Competing interests}

The authors declare that they have no competing interests.

\section{Consent for publication}

Not applicable.

Ethics approval and consent to participate

Not applicable.

\section{Author details}

${ }^{1}$ Florida Museum of Natural History, University of Florida, 1659 Museum Road, PO Box 117800, Gainesville, Florida 32611, USA. ${ }^{2}$ Oertijdmuseum De Groene Poort, Bosscheweg 80, NL-5283 WB Boxtel, The Netherlands.

${ }^{3}$ Department of Integrative Biology and Museum of Paleontology, University of California, Berkeley, 1005 Valley Life Sciences Building \#3140, Berkeley, California 94720, USA. ${ }^{4}$ Natural History Museum of Denmark, Geological Museum, University of Copenhagen, Øster Voldgade 5-7, 1350 Copenhagen K, Denmark. ${ }^{5}$ Geological Survey of Denmark and Greenland, GEUS, Øster Voldgade 10, 1350 Copenhagen K, Denmark.

Received: 4 December 2015 Accepted: 28 May 2016 Published online: 16 June 2016

\section{References}

1. Freiwald A, Roberts JM. Cold-water corals and ecosystems. Berlin/Heidelberg: Springer-Verlag; 2005.

2. Taviani M, Freiwald A, Zibrowius H. Deep coral growth in the Mediterranean Sea: an overview. In: Freiwald A, Roberts JM, editors. Cold-water corals and ecosystems. Berlin/Heidelberg: Springer; 2005. p. 137-56.

3. Hovland M. Deep-water coral reefs: Unique biodiversity hot-spots. Berlin: Springer-Verlag \& Chichester: Praxis; 2008

4. Roberts JM, Wheeler AJ, Freiwald A, Cairns SD. Cold-water corals: the biology and geology of deep-sea coral habitats. New York: Cambridge University Press; 2009.

5. Cathalot C, Van Oevelen D, Cox TJS, Kutti T, Lavaleye MS, Duineveld G, Meysman FJR. Cold-water coral reefs and adjacent sponge grounds: Hotspots of benthic respiration and organic carbon cycling in the deep sea. Frontiers Mar Sci. 2015;2:37.

6. Henry L-A, Roberts JM. Global biodiversity in cold-water coral reef ecosystems. In: Rossi S, editor. Marine Animal Forests. Springer; 2016. DOI:10.1007/978-3-319-17001-5_6-1

7. Roberts JM, Wheeler AJ, Freiwald A. Reefs of the deep: the biology and geology of cold-water coral ecosystems. Science. 2006;312(5773):543-7.

8. Hoegh-Guldberg O, Mumby PJ, Hooten AJ, Steneck RS, Greenfield P, Gomez

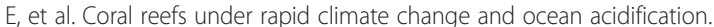
Science. 2007;318(5857):1737-42. 
9. Pandolfi JM, Connolly SR, Marshall DJ, Cohen AL. Projecting coral reef futures under global warming and ocean acidification. Science. 2011; 333(6041):418-22.

10. Kennedy EV, Perry CT, Halloran PR, Iglesias-Prieto R, Schönberg CH, Wisshak $\mathrm{M}$, et al. Avoiding coral reef functional collapse requires local and global action. Curr Biol. 2013;23:912-8.

11. Descombes P, Wisz MS, Leprieur F, Parravicini V, Heine C, Olsen SM, et al. Forecasted coral reef decline in marine biodiversity hotspots under climate change. Glob Chang Biol. 2015;21:2479-87.

12. Freiwald A, Fosså JH, Grehan A, Koslow T, Roberts JM. Cold-water coral reefs. Cambridge: UNEP-WCMC; 2004

13. Lauridsen BW, Bjerager M. Danian cold-water corals from the Baunekule facies, Faxe Formation, Denmark: a rare taphonomic window of a coral mound flank habitat. Lethaia. 2014;47:437-55.

14. Buhl-Mortensen L, Mortensen PB. Symbiosis in deep-water corals. Symbiosis. 2004;37:33-61.

15. Buhl-Mortensen L, Mortensen PB. Distribution and diversity of species associated with deep-sea gorgonian corals off Atlantic Canada. In: Freiwald A, Roberts JM, editors. Cold-water corals and ecosystems. Berlin/Heidelberg: Springer; 2005. p. 849-79.

16. Henry L-A, Roberts JM. Biodiversity and ecological composition of macrobenthos on cold-water coral mounds and adjacent off-mound habitat in the bathyal Porcupine Seabight, NE Atlantic. Deep-Sea Res Part 1. 2007; 54:654-72.

17. Danovaro R, Corinaldesi C, D’Onghia G, Galil B, Gambi C, Gooday AJ, et al. Deep-sea biodiversity in the Mediterranean Sea: The known, the unknown and the unknowable. PLoS ONE. 2010;5(8):e11832.

18. Ramirez-Llodra E, Brandt A, Danovaro R, De Mol B, Escobar E, German C, et al. Deep, diverse and definitely different: unique attributes of the world's largest ecosystem. Biogeosciences. 2010;7:2851-99.

19. Davies AJ, Duineveld G, Lavaleye M, Bergman M, Van Haren H, Roberts JM. Downwelling and deep-water bottom currents as food supply mechanisms to the cold-water coral Lophelia pertusa (Scleractinia) at the Mingulay Reef Complex. Limnol Oceanogr. 2009;54:620-9.

20. Jones CG, Lawton JH, Shachak M. Organisms as ecosystem engineers. Oikos. 1994;69:373-86.

21. Erwin DH. Macroevolution of ecosystem engineering, niche construction and diversity. Trends Ecol Evol. 2008;23:304-10

22. Reed JK, Gore RH, Scotto LE, Wilson KA. Community composition, structure, areal and trophic relationships of decapods associated with shallow-and deep-water Oculina varicosa coral reefs: studies on decapod Crustacea from the Indian River region of Florida, XXIV. Bull Mar Sci. 1982;32:761-86.

23. Reed JK. Deep-water Oculina coral reefs of Florida: biology, impacts, and management. Hydrobiologia. 2002;471:43-55.

24. Vertino A, Savini A, Rosso A, Di Geronimo I, Mastrototaro F, Sanfilippo R, et al. Benthic habitat characterization and distribution from two representative sites of the deep-water SML coral province (Mediterranean) Deep-Sea Res Part 2. 2010;57:380-96.

25. Müller P. Decapod Crustacea of the Badenian. Geologica Hungarica, Series Palaeontologica. 1984;42:3-317

26. Fraaije RHB. Evolution of reef-associated decapod crustaceans through time, with particular reference to the Maastrichtian type area. Contrib Zool. 2003; 72:119-30.

27. Beschin C, Busulini A, De Angeli A, Tessier G. I Decapodi dell'Eocene inferiore di Contrada Gecchelina (Vicenza - Italia settentrionale) (Anomura e Brachyura). Museo di Archeologia e Scienze Naturali "G. Zannato". Montecchio Maggiore (Vicenza). 2007;2007:5-76.

28. Gatt M, De Angeli A. A new coral-associated decapod assemblage from the Upper Miocene (Messinian) Upper Coralline Limestone of Malta (Central Mediterranean). Palaeontology. 2010;53:1315-48

29. Klompmaker AA, Ortiz JD, Wells NA. How to explain a decapod crustacean diversity hotspot in a mid-Cretaceous coral reef. Palaeogeogr Palaeoclimatol Palaeoecol. 2013;374:256-73.

30. Klompmaker AA, Schweitzer CE, Feldmann RM, Kowalewski M. The influence of reefs on the rise of Mesozoic marine crustaceans. Geology. 2013;41:1179-82.

31. Beschin C, Busulini A, Tessier G. Nuova segnalazione di crostacei associati a coralli nell'Eocene inferiore dei Lessini orientali (Vestenanova - Verona). Lavori Società Veneziana di Scienze Naturali. 2015:40:47-109.

32. Mortensen PB, Hovland M, Brattegard T, Farestveit R. Deep water bioherms of the scleractinian coral Lophelia pertusa (L.) at $64^{\circ} \mathrm{N}$ on the Norwegian shelf: structure and associated megafauna. Sarsia. 1995;80:145-58.
33. Krieger KJ, Wing BL. Megafauna associations with deepwater corals (Primnoa spp.) in the Gulf of Alaska. Hydrobiologica. 2002:471:83-90.

34. Roberts JM, Henry L-A, Long D, Hartley JP. Coldwater coral reef frameworks, megafaunal communities and evidence for coral carbonate mounds on the Hatton Bank, north east Atlantic. Facies. 2008;54:297-316.

35. Mastrototaro F, D'Onghia G, Corriero G, Matarrese A, Maiorano P, Panetta P, et al. Biodiversity of the white coral bank off Cape Santa Maria di Leuca (Mediterranean Sea): An update. Deep-Sea Res Part II. 2010;57:412-30.

36. D'Onghia G, Mairorano P, Sion L, Giove F, Capezzuto F, Carlucci R, Tursi A. Effects of deep-water coral banks on the abundance and size structure of the megafauna in the Mediterranean Sea. Deep-Sea Res Part I. 2010;57:397-411.

37. D'Onghia G, Indennidate A, Giove A, Savini A, Capezzuto F, Sion L, et al. Distribution and behaviour of deep-sea benthopelagic fauna observed using towed cameras in the Santa Maria di Leuca cold-water coral province. Mar Ecol Prog Ser. 2011;443:95-110.

38. Capezzuto F, Maiorano P, Panza M, Indennidate A, Sion L, D'Onghia G. Occurrence and behaviour of Paromola cuvieri (Crustacea, Decapoda) in the Santa Maria di Leuca cold-water coral community (Mediterranean Sea). Deep-Sea Res Part I. 2012;59:1-7.

39. Purser A, Ontrup J, Schoening T, Thomsen L, Tong R, Unnithan V, et al. Microhabitat and shrimp abundance within a Norwegian cold-water coral ecosystem. Biogeosciences. 2013;10:5779-91.

40. Taviani M, Angeletti L, Canese S, Cannas R, Cardone F, Cau A, et al. The "Sardinian cold-water coral province" in the context of the Mediterranean coral ecosystems. Deep-Sea Res Part II. 2015. doi:10.1016/j.dsr2.2015.12.008.

41. Cairns SD, Stanley Jr GD. Ahermatypic coral banks: living and fossil counterparts. Proceedings Fourth International Coral Reef Symposium. 1982;2:611-8.

42. Stanley Jr GD, Cairns SD. Constructional azooxanthellate coral communities: an overview with implications for the fossil record. Palaios. 1988;3:233-42.

43. Vertino A, Stolarski J, Bosellini FR, Taviani M. Mediterranean corals through time: From Miocene to present. In: Goffredo S, Dubinsky Z, editors. The Mediterranean Sea: Its history and present challenges. Dordrecht/Heidelberg/ New York/London: Springer; 2014. p. 257-74.

44. Di Geronimo I, Messina C, Rosso A, Sanfilippo R, Sciuto F, Vertino A Enhanced biodiversity in the deep: Early Pleistocene coral communities from southern Italy. In: Freiwald A, Roberts JM, editors. Cold-water corals and ecosystems. Berlin/Heidelberg: Springer; 2005. p. 61-86.

45. Titschack J, Freiwald A. Growth, deposition, and facies of Pleistocene bathyal coral communities from Rhodes, Greece. In: Freiwald A, Roberts JM, editors. Cold-water corals and ecosystems. Berlin/Heidelberg: Springer; 2005. p. 41-59.

46. Taviani M, Vertino A, López Correa M, Savini A, De Mol B, Remia A, et al. Pleistocene to Recent scleractinian deep-water corals and coral facies in the Eastern Mediterranean. Facies. 2011;57:579-603.

47. Titschack J, Joseph N, Fietzke J, Freiwald A, Bromley RG. Record of a tectonically-controlled regression captured by changes in carbonate skeletal associations on a structured island shelf (mid-Pleistocene, Rhodes, Greece). Sediment Geol. 2013;283:15-33

48. von Fischer-Benzon R. Über das relativ Alter des Faxoe-Kalkes und über die in demselben vorkommenden Anomuren und Brachyuren. Kiel: Schweis'sche Buchhandlung: 1866.

49. Segerberg KO. De Anomura och Brachyura Decapoderna inöm Scändinaviens Yngra Krita. Geol Fören Stockh Förh. 1900;22:347-90.

50. Collins JSH, Jakobsen SL. A synopsis of the biostratigraphic distribution of the crab genera (Crustacea, Decapoda) of the Danian (Palaeocene) of Denmark and Sweden. Bull Mizunami Fossil Mus. 1994;21:35-46.

51. Jakobsen SL, Collins JSH. New middle Danian species of anomurans and brachyuran crabs from Fakse, Denmark. Bull Geol Soc Den. 1997;44:89-100.

52. Jakobsen SL. A new preparatory approach of decapod and thoracican crustaceans from the Middle Danian at Fakse, Denmark. Contrib Zool. 2003;72:141-5.

53. Jakobsen SL, Feldmann RM. Epibionts on Dromiopsis rugosus (Decapoda: Brachyura) from the late Middle Danian limestones at Fakse Quarry, Denmark: novel preparation techniques yield amazing results. J Paleontol. 2004;78:953-60

54. Bernecker M, Weidlich O. Azooxanthellate corals in the Late MaastrichtianEarly Paleocene of the Danish basin: bryozoan and coral mounds in a boreal shelf setting. In: Freiwald A, Roberts JM, editors. Cold-water corals and ecosystems. Berlin/Heidelberg: Springer; 2005. p. 3-25. 
55. Damholt T, Rasmussen A, Rasmussen L. Fossiler fra Faxe Kalkbrud. Geomuseum Faxe: Faxe; 2010.

56. Polkowsky S. Krebse und Krabben aus norddeutschen Geschieben Lobsters and crabs from erratics in northern Germany, Tassados 2 Norderstedt: Books on Demand; 2014.

57. Hennig A. Studier öfver den baltiska Yngre kritans bildningshistoria. Geol Fören Stockh Förh. 1899;21 (19-82):133-88.

58. Nielsen KB. Zoantharia from Senone and Paleocene deposits in Denmark and Skaane. Det Kongelige Danske Videnskabernes Selskabs Skrifter 8. Række. Naturvidenskabelig og Mathematisk Afdeling. 1922;3:199-233.

59. Lyell C. On the Cretaceous and Tertiary Strata of the Danish Islands of Seeland and Moen. Trans Geological Soc London. 1837;6:243-57.

60. Lauridsen BW, Bjerager M, Surlyk F. The middle Danian Faxe Formation new lithostratigraphic unit and a rare taphonomic window into the Danian of Denmark. Bull Geol Soc Den. 2012;60:47-60.

61. Warrant EJ, Locket NA. Vision in the deep sea. Biol Rev. 2004;79:671-712.

62. Asgaard U. 1968. Brachiopod palaeoecology in middle Danian limestones at Fakse, Denmark. Lethaia. 1968;1:103-21.

63. Donovan SK, Jakobsen SL. An unusual crinoid-barnacle association in the type area of the Danian (Paleocene, Denmark). Lethaia. 2004;37:407-15.

64. Lauridsen BW, Schnetler Kl. A catalogue of Danian gastropods from the Baunekule facies, Faxe Formation, Denmark. Geological Survey of Denmark and Greenland Bulletin. 2014:32:1-117.

65. Hammer $\varnothing$, Harper DAT, Ryan PD. Past: Paleontological statistics software package for education and data analysis. Palaeontol Electronica. 2001;4(1), art. 4:1-9.

66. Kiessling W. Secular variations in the Phanerozoic reef ecosystem. In: Kiessling W, Flügel E, Golonka J, editors. Phanerozoic Reef Patterns. Tulsa, Society for Sedimentary Geology Special Publication 72; 2002. p. 625-90.

67. Reuss AE. Über kurzschwänzige Krebse im Jurakalke Mährens. Sitzungsberichte der Kaiserlichen Akademie der Wissenschaften, (Mathematischnaturwissenschaftliche Classe). 1858:31:5-13.

68. von Schlotheim EF. Die Petrefactenkunde auf ihrem jetztigen Standpunkte durch die Beschreibung seiner Sammlung versteinerter und fossiler Überreste des Thierund Pflanzenreichs der Vorwelt erläutert. Gotha: Becker'sche Buchhandlung; 1820.

69. Abele LG. Comparative species composition and relative abundance of decapod crustaceans in marine habitats of Panama. Mar Biol. 1976;38: 263-78.

70. Collins JSH, Fraaye RHB, Jagt JWM. Late Cretaceous anomurans and brachyurans from the Maastrichtian type area. Acta Palaeontol Pol. 1995;40:165-210.

71. Jagt JWM, Fraaije RHB, Van Bakel BWM. Decapod crustacean 'odds and ends' from the Maastrichtian type area (southeast Netherlands, northeast Belgium). Scr Geol. 2014;147:95-115.

72. Hiller-Adams P, Case JF. Optical parameters of the eyes of some benthic decapods as a function of habitat depth (Crustacea, Decapoda). Zoomorphology. 1985;105:108-13.

73. Klompmaker AA, Artal P, Van Bakel BWM, Fraaije RHB, Jagt JWM. Etyid crabs (Crustacea, Decapoda) from mid-Cretaceous reefal strata of Navarra, northern Spain. Palaeontology. 2011;54:1199-212.

74. Klompmaker AA, Hyžný M, Jakobsen SL. Taphonomy of decapod crustacean cuticle and its effect on the appearance as exemplified by new and known taxa from the Cretaceous-Danian crab Caloxanthus. Cretac Res. 2015;55: 141-51.

75. Frantescu AL. Comparative study of the Eocene fossil decapod crustaceans of the North American Atlantic coast and European Tethyan provinces. Dissertation, Kent State University; 2013

76. Lindberg WJ, Stanton G. Bryozoan-associated decapod crustaceans: community patterns and a case of cleaning symbiosis between a shrimp and crab. B Mar Sci. 1988:42:411-23.

77. Cocito S. Bioconstruction and biodiversity: their mutual influence. Sci Mar. 2004;68(S1):137-44.

78. Wood ACL, Probert PK, Rowden AA, Smith AM. Complex habitat generated by marine bryozoans: a review of its distribution, structure, diversity, threats and conservation. Aquat Conserv. 2012;22:547-63.

79. Lombardi C, Taylor PD, Cocito S. Bryozoan constructions in a changing Mediterranean Sea. In: Goffredo S, Dubinsky Z, editors. The Mediterranean Sea: Its history and present challenges. Dordrecht/Heidelberg/New York/ London: Springer; 2014. p. 373-84.

80. Henry L-A, Davies AJ, Roberts JM. Beta diversity of cold-water coral reef communities off western Scotland. Coral Reefs. 2010;29:427-36.
81. Bishop GA. Taphonomy of the North American decapods. J Crustacean Biol. 1986;6:326-55.

82. Plotnick RE. Taphonomy of a modern shrimp: Implications for the arthropod fossil record. Palaios. 1986;1:286-93.

83. Jagt JWM, Jagt-Yazykova EA. Stratigraphy of the type Maastrichtian-a synthesis. Fossils of the type Maastrichtian (Part 1). Scr Geol. Special Issue. 2012;8:5-32.

84. Buhl-Mortensen P, Buhl-Mortensen L, Purser A. Trophic ecology and habitat provision in cold-water coral ecosystems. In: Rossi S, editor. Marine Animal Forests. Springer; 2016. DOl:10.1007/978-3-319-17001-5_20-1

85. Alvarez LW, Alvarez W, Asaro F, Michel HV. Extraterrestrial cause for the Cretaceous-Tertiary extinction. Science. 1980;208(4448):1095-108.

86. MacLeod N, Rawson PF, Forey PL, Banner FT, Boudagher-Fadel MK, Bown PR, et al. The Cretaceous-Tertiary biotic transition. J Geol Soc London. 1997;154:265-92.

87. Schulte P, Alegret L, Arenillas I, Arz JA, Barton PJ, Bown PR, et al. The Chicxulub asteroid impact and mass extinction at the Cretaceous-Paleogene boundary. Science. 2010;327(5970):1214-8.

88. Klompmaker AA. 2013. Extreme diversity of decapod crustaceans from the mid-Cretaceous (late Albian) of Spain: implications for Cretaceous decapod paleoecology. Cretac Res. 2013;41:150-85.

89. Schweitzer CE, Feldmann RM. Decapod crustaceans, the K/P event, and Palaeocene recovery. In: Koenemann S, Jenner RA, editors. Crustacea and arthropod relationships Crustacean Issues 16. Boca Raton: CRC/Taylor \& Francis; 2005. p. 17-53.

90. Brösing A. A reconstruction of an evolutionary scenario for the Brachyura (Decapoda) in the context of the Cretaceous-Tertiary boundary. Crustaceana. 2008;81:271-87.

91. Rathbun MJ. Fossil Crustacea of the Atlantic and Gulf Coastal Plain. Geol Soc Am Spec Pap. 1935;2:1-160.

92. Armstrong A, Nyborg T, Bishop GA, Ossó-Morales À, Vega FJ. Decapod crustaceans from the Paleocene of Central Texas. USA Revista Mexicana de Ciencias Geológicas. 2009;26:745-63.

93. Távora VA, Paixão GMC, Silva FA. Considerações filogenéticas e biogeografia histórica dos malacostráceos (decápodes e isópodes) cenozóicos do Brasil. Rev Bras Geociências. 2010;40:47-58.

94. Hyžný M, Perrier V, Robin N, Martin JE, Sarr R. Costacopluma (Decapoda: Brachyura: Retroplumidae) from the Maastrichtian and Paleocene of Senegal: A survivor of K/Pg events. Cretac Res. 2016;57:142-56.

95. Martínez-Díaz JL, Phillips GE, Nyborg T, Espinosa B, Távora VA, CentenoGarcía E, et al. Lilliput effect in a retroplumid crab (Crustacea: Decapoda) across the K/Pg boundary. J S Am Earth Sci. 2016;69:11-24.

96. Steele DH. Latitudinal variations in body size and species diversity in marine decapod crustaceans of the continental shelf. Internationale Revue der gesamten Hydrobiologie und Hydrographie. 1988;73:235-46.

97. Dworschak PC. Global diversity in the Thalassinidea (Decapoda): an update (1998-2004). Nauplius. 2005;13:57-63.

98. Mauchline J. The biology of bathypelagic organisms, especially Crustacea. Deep-Sea Res. 1972;19:753-80.

99. Sastry AN. Ecological aspects of reproduction. In: Bliss DE, editor. The Biology of Crustacea 8. Environmental adaptations. New York: Academic Press; 1983. p. 179-270.

100. Poulin R. Evolutionary influences on body size in free-living and parasitic isopods. Biol J Linn Soc Lond. 1995;54:231-44.

101. Poulin R. Clutch size and egg size in free-living and parasitic copepods: a comparative analysis. Evolution. 1995;49:325-36.

102. Poulin R, Hamilton WJ. Ecological determinants of body size and clutch size in amphipods: a comparative approach. Funct Ecol. 1995;9:364-70.

103. Timofeev SF. Bergmann's principle and deep-water gigantism in marine crustaceans. Biol Bull Russ Acad Sci. 2001;28:646-50.

104. Steele DH, Steele VJ. The biology of Gammarus (Crustacea, Amphipoda) in the northwestern Atlantic. XI. Comparison and discussion. Can J Zool. 1975;53:1116-26.

105. Clarke A. On living in cold water: K-strategies in Antarctic benthos. Mar Biol. 1979;55:111-9.

106. Wallerstein BR, Brusca RC. Fish predation: a preliminary study of its role in the zoogeography and evolution of shallow water idoteid isopods (Crustacea: Isopoda: Idoteidae). J Biogeogr. 1982:9:135-50.

107. Manyak-Davis A, Bell TM, Sotka EE. The relative importance of predation risk and water temperature in maintaining Bergmann's rule in a marine ectotherm. Am Nat. 2013;182:347-58. 
108. Jones GP, McCormick MI, Srinivasan M, Eagle JV. Coral decline threatens fish biodiversity in marine reserves. Proc Natl Acad Sci U S A. 2004;101(21):8251-3.

109. Gratwicke B, Speight MR. The relationship between fish species richness, abundance and habitat complexity in a range of shallow tropical marine habitats. J Fish Biol. 2005;66:650-67.

110. Klompmaker AA, Schweitzer CE, Feldmann RM, Kowalewski M. Environmental and scale-dependent evolutionary trends in the body size of crustaceans. Proc R Soc B. 2015;282:20150440.

111. Meyer J-C. Le récif danien de Vigny. SAGA Informations, Géoguide de la Société amicale des Géologues amateurs. 1987;26:1-72.

112. Montenat C, Barrier P, D'Estevou PO. The Vigny limestones: a record of Palaeocene (Danian) tectonic-sedimentary events in the Paris Basin. Sedimentology. 2002;49:421-40.

113. Land MF, Nilsson DE. Animal eyes. Oxford: Oxford University Press; 2012.

114. Hiller-Adams P, Case JF. Optical parameters of euphausiid eyes as a function of habitat depth. J Comp Physiol A. 1984;154:307-18.

115. Hiller-Adams P, Case JF. Eye size of pelagic crustaceans as a function of habitat depth and possession of photophores. Vision Res. 1988;28:667-80.

116. Feldmann RM, Schweitzer CE, Wahl WR. Ekalakia (Decapoda: Brachyura): the preservation of eyes links Cretaceous crabs to Jurassic ancestors. J Paleontol. 2008;82:1030-4.

117. Tanaka G, Smith RJ, Siveter DJ, Parker AR. Three-dimensionally preserved decapod larval compound eyes from the Cretaceous Santana Formation of Brazil. Zoolog Sci. 2009;26:846-50.

118. Pinna G. Gli Erionidei della nuova fauna sinemuriana a crostacei decapodi di Osteno in Lombardia. Atti della Società italiana di Scienze naturali e del Museo civico di Storia naturale in Milano. 1968;107(2):93-134.

119. Teruzzi G. The genus Coleia Broderip, 1835 (Crustacea, Decapoda) in the Sinemurian of Osteno in Lombardy. Atti della Società Italiana di Scienze Naturali e del Museo Civico di Storia Naturale di Milano. 1990;131(4):85-104.

120. Maisey JG, De Carvalho MDGP. First records of fossil sergestid decapods and fossil brachyuran crab larvae (Arthropoda, Crustacea), with remarks on some supposed palaemonid fossils, from the Santana Formation (Aptian-Albian, NE Brazil). Am Mus Novit. 1995;3132:1-17.

121. Charbonnier S, Vannier J, Hantzpergue P, Gaillard C. Ecological significance of the arthropod fauna from the Jurassic (Callovian) La Voulte Lagerstätte. Acta Palaeontol Pol. 2009;55:111-32.

122. Audo D, Schweigert G, Haug JT, Haug C, Saint Martin JP, Charbonnier S. Diversity and palaeoecology of the enigmatic genus Knebelia (Eucrustacea, Decapoda, Eryonidae) from upper Jurassic Plattenkalks in southern Germany. Palaeontology. 2014;57:397-416.

123. Haug JT, Audo D, Haug C, Saad PA, Petit G, Charbonnier S. Unique occurrence of polychelidan lobster larvae in the fossil record and its evolutionary implications. Gondwana Res. 2014;28:869-74.

124. Vega FJ, Jackson J, Ossó À. Exceptional preservation of a late Cenomanian (Late Cretaceous) crab from Texas, USA. Bol Soc Geol Mex. 2014;66:215-21.

125. Haug JT, Martin JW, Haug C. A 150-million-year-old crab larva and its implications for the early rise of brachyuran crabs. Nat Commun. 2015;6:6417.

126. Luque J. A puzzling frog crab (Crustacea: Decapoda: Brachyura) from the Early Cretaceous Santana Group of Brazil: frog first or crab first? J Syst Palaeontol. 2015;13:153-66.

127. Smith AB, McGowan AJ. The shape of the Phanerozoic marine palaeodiversity curve: how much can be predicted from the sedimentary rock record of Western Europe? Palaeontology. 2007;50:765-74.

128. Mortensen PB, Fosså JH. Species diversity and spatial distribution of invertebrates on deep-water Lophelia reefs in Norway. Proceedings of 10th International Coral Reef Symposium. 2006. p. 1849-68.

129. Reyes J, Santodomingo N, Gracia A, Borrero-Pérez G, Navas G, Mejía-Ladino $L$, et al. Southern Caribbean azooxanthellate coral communities off Colombia. In: Freiwald A, Roberts JM, editors. Cold-water corals and ecosystems. Berlin/Heidelberg: Springer; 2005. p. 309-30.

130. Abele LG. Species diversity of decapod crustaceans in marine habitats. Ecology. 1974;55:156-61.

131. Abele LG. The community structure of coral-associated decapod crustaceans in variable environments. In: Livingston RJ, editor. Ecological processes in coastal and marine systems. New York: Plenum Press; 1979. p. 265-87.

132. Martínez Iglesias JC, García Raso JE. The crustacean decapod communities of three coral reefs from the southwestern Caribbean Sea of Cuba: species composition, abundance and structure of the communities. B Mar Sci. 1999:65:539-57.
133. Black R, Prince J. Fauna associated with the coral Pocillopora damicornis at the southern limit of its distribution in Western Australia. J Biogeogr. 1983;10:135-52.

134. Plaisance L, Knowlton N, Paulay G, Meyer C. Reef-associated crustacean fauna: biodiversity estimates using semi-quantitative sampling and DNA barcoding. Coral Reefs. 2009;28:977-86.

135. Collins JSH. New species of crabs (Crustacea, Decapoda), one from the Middle Danian of Denmark, and three new species from the Upper Cretaceous of Nigeria. Bulletin of the Mizunami Fossil Museum. 2010;36:13-9.

136. Jagt JWM, Collins JSH, Fraaye RHB. A new late Maastrichtian xanthid crab from southern Limburg (the Netherlands). Cretac Res. 1991;12:553-60.

137. Fraaye RHB. Two new crabs, Graptocarcinus maastrichtensis, and Caloxanthus kuypersi (Crustacea, Decapoda), from the Maastrichtian of the Netherlands. J Paleontol. 1996;70:463-5.

138. Fraaye RHB. A new Tethyan migrant: Cretachlorodius enciensis n. gen., n. sp. (Crustacea, Decapoda), from the Maastrichtian type area. J Paleontol. 1996;70:293-6.

139. Fraaye RHB. Late Cretaceous swimming crabs: radiation, migration, competition, and extinction. Acta Palaeontol Pol. 1996:46:269-78.

140. Fraaye RHB, Van Bakel BWM. New raninid crabs (Crustacea, Decapoda, Brachyura) from the late Maastrichtian of the Netherlands. Geol Mijnb. 1998;76:293-9.

141. Swen C, Fraaije RHB, Van der Zwaan GJ. Polymorphy and extinction of the Late Cretaceous burrowing shrimp Protocallianassa faujasi and first record of the genera Corallianassa and Calliax (Crustacea, Decapoda, Thalassinoidea) from the Cretaceous. Contrib Zool. 2001;70:85-98.

142. Fraaije RHB. New calappid crabs (Crustacea, Decapoda, Brachyura) from the Late Maastrichtian of the Netherlands. J Paleontol. 2002;76:913-7.

143. Fraaije RHB, Van Bakel BWM, Jagt JWM, Klompmaker AA, Artal P. A new hermit crab (Crustacea, Anomura, Paguroidea) from the mid-Cretaceous of Navarra, northern Spain. Bol Soc Geol Mex. 2009;61:13-6.

144. Fraaije RHB, Artal P, Van Bakel BWM, Jagt JWM, Klompmaker AA. An array of sixth abdominal tergite types of paguroid anomurans (Crustacea) from the mid-Cretaceous of Navarra, northern Spain. Neth J Geosci. 2013:92:109-17.

145. Fraaije RHB, Klompmaker AA, Artal P. New species, genera and a family of hermit crabs (Crustacea, Anomura, Paguroidea) from a mid-Cretaceous reef of Navarra, northern Spain. Neues Jahrb Geol Palaontol Abh. 2012;263:85-92.

146. Klompmaker AA, Artal P, Fraaije RHB, Jagt JWM. Revision of the family Gastrodoridae (Crustacea, Decapoda), with description of the first species from the Cretaceous. J Paleontol. 2011:85:226-33.

147. Klompmaker AA, Feldmann RM, Robins CM, Schweitzer CE. Peak diversity of Cretaceous galatheoids (Crustacea, Decapoda) from northern Spain. Cretac Res. 2012;36:125-45.

148. Klompmaker AA, Artal P, Gulisano G. The Cretaceous crab Rathbunopon: revision, a new species and new localities. Neues Jahrb Geol Palaontol Abh. 2011;260:191-202

149. Klompmaker AA, Feldmann RM, Schweitzer CE. A hotspot for Cretaceous goniodromitids (Decapoda, Brachyura) from reef associated strata in Spain. J Crustacean Biol. 2012;32:780-801.

\section{Submit your next manuscript to BioMed Central and we will help you at every step:}

- We accept pre-submission inquiries

- Our selector tool helps you to find the most relevant journal

- We provide round the clock customer support

- Convenient online submission

- Thorough peer review

- Inclusion in PubMed and all major indexing services

- Maximum visibility for your research

Submit your manuscript at www.biomedcentral.com/submit 